\begin{tabular}{|c|c|c|}
\hline & Int.J.Curr.Microbiol.App.Sci (2021) 10(08): 149-155 & \\
\hline & $\begin{array}{l}\text { International Journal of Current Micro6iology and Applied Sciences } \\
\text { ISSN: 2319-7706 Volume } \mathbf{1 0} \text { Number } \mathbf{0 8}(\mathbf{2 0 2 1}) \\
\text { Journal homepage: http://www.ijcmas.com }\end{array}$ & $\begin{array}{l}50 \\
502\end{array}$ \\
\hline $\begin{array}{l}\text { EXCELLENT } \\
\text { PUBLISHERS }\end{array}$ & & whwe.jicmascom \\
\hline
\end{tabular}

Original Research Article

https://doi.org/10.20546/ijcmas.2021.1008.019

\title{
Effect of Agrometeorological Parameters on Turcicum Leaf Blight Disease of Maize in Northern Transition Zone of Karnataka
}

\author{
Vishal Meti*, K. G. Sumesh, H. Venkatesh and S. I. Harlapur \\ Department of Agricultural Meteorology, College of Agriculture, Dharwad University of \\ Agricultural Sciences, Dharwad - 580 005, Karnataka, India
}

*Corresponding author

\section{A B S T R A C T}

\section{Keywords}

Growing

Environment, Lead

Time, Per cent

Disease Index and

Real Time

Article Info

Accepted:

12 July 2021

Available Online:

10 August 2021
The role of agrometeorological parameters on turcicum leaf blight disease of maize have been studied to establish for warming procedure for timely preventive measure against this disease, the crop was sown under three distinct Growing Environment(GE) were created for the maize crop. This helped in creating contrasting environmental conditions to facilitate occurrence of disease. This disease was lowest in $\mathrm{GE}_{1}$ (35 per cent disease index) at 105 days after sowing (DAS), whereas, highest in case of $\mathrm{GE}_{3}$ (80 per cent disease index) at 108 days after sowing (DAS) and was intermediate at $\mathrm{GE}_{2}$ (65 per cent disease index) at 105 days after sowing (DAS). Regression analysis was performed for estimating the per cent disease index using agrometeorological and micrometeorological variable as independent parameters as three days lead time $\left(\mathrm{LT}_{3}\right)$, Six days lead time $\left(\mathrm{LT}_{6}\right)$ and real time $\left(\mathrm{LT}_{0}\right)$. In real time $\left(\mathrm{LT}_{0}\right)$ variable $\mathrm{X}_{13}$ (morning relative humidity at top of the canopy), variable $\mathrm{X}_{19}$ (morning relative humidity at bottom of the canopy), variable $\mathrm{X}_{23}$ (Afternoon air temperature in Observatory) In three days lead time $\left(\mathrm{LT}_{3}\right)$ and six days lead time $\left(\mathrm{LT}_{6}\right)$ variable $\mathrm{X}_{26}$ (Afternoon relative humidity in Observatory) were considered weather parameters in the optimized model which are important for forecasting of disease incidence.

\section{Introduction}

Maize (Zea mays L.) is a important cereal crop in agricultural economy of the world. Maize is known as queen of cereals because of its high genetic yield potential among the cereals. It is cultivated in an area of $177 \mathrm{~m}$ ha in about 160 countries with production of $967 \mathrm{~m}$ tons and productivity of 4.92 tons per ha (Anon, 2019).
The major producer of maize are USA, China, Brazil, Mexico, Argentina, South Africa and India. The USA is largest producer of maize contribute 55 per cent of the total production. In India it is grown over an area of $9.56 \mathrm{~m}$ ha with production of $28.7 \mathrm{~m}$ tons with an average productivity of $3006 \mathrm{~kg}$ per ha (Anon, 2020). Predominant maize growing states in India are Andhra Pradesh, Karnataka, 
Maharashtra, Madhya Pradesh and Punjab. In Karnataka maize occupies an area of $1.37 \mathrm{~m}$ ha with production of $3.31 \mathrm{~m}$ tons and the productivity of $2419 \mathrm{~kg}$ per ha. The major growing districts in Karnataka are Bagalkot, Belgavi, Bellary, Haveri, Dharwad, Vijaypura, Chitradurga, Gadag and Davangere.

The low productivity of maize both at national and state level can be attributed to biotic stress like weed, insect pest and diseases and abiotic stress mainly drought, flood, salinity etc. Among these, diseases often pose a serious threat to maize production and increase the cost of cultivation and impair the quality of the produce in many ways. It is estimated that 16 out of 61 diseases adversely affecting this crop have been identified as major ones (Payak and Sharma, 1982). In recent years it is revealed that the losses in yield due to major foliar disease of maize India is about 13.2 per cent. Among the foliar diseases Turcicum leaf blight (Exserohilium turcicum), Common rust (Puccinia sorghi) and Curvularia leaf spot (Curvularia lunata) have been a major threat to the cultivation of maize crop in Northern transitition zone of Karnataka. In this context one should know how much loss occurs due to damage and interrelationships between disease and weather factor. It is also well know that the biotic factors themselves are affected by the abiotic environmental situation like rainfall distribution, sunshine hours, temperature and humidity parameters. Same is the case of disease maize. This gives an opportunity to use the association between the abiotic and biotic events for warming of biotic factors.

\section{Materials and Methods}

A field experiment was conducted was during Kharif season of 2018 at Main Agricultural Research Station (MARS), University Agricultural Sciences (UAS) Dharwad, Karnataka, India. By providing staggered sowing windows different Growing Environment (GE) were created for the maize crop. The experiments comprised of three growing environment as per the treatments. Sowing for the first growing environment was carried out on $15^{\text {th }}$ June $\left(24^{\text {th }}\right.$ SMW), for the second growing environment it was carried out on $30^{\text {th }}$ June $\left(26^{\text {th }}\right.$ SMW) and the third growing environment it was carried out $18^{\text {th }}$ July $\left(29^{\text {th }} \mathrm{SMW}\right)$. This helped in creating different environmental condition to facilitate prevalence of disease incidence. Agrometeorological and micrometeorological observation were taken at 0730 LMT and 1430 LMT at three days interval. Canopy temperature was measured with the help of infrared thermometer, air temperature and relative humidity were measured at top, middle and bottom of the canopy by weather tracker. The photosynthetically active radiation (PAR) was measured at top, middle and bottom of the canopy with help of Line quantum sensor. agrometeorological observatory data namely temperature, relative humidity and rainfall were collected from the records of the Department of Agricultural Meteorology, UAS, Dharwad. Observation on disease were made at three days intervals from randomly selected ten plants of each plots.

The SPSS 16.0 software was used for multiple regression analysis. The three days lead time $\left(\mathrm{LT}_{3}\right)$ means the data on agrometeorological and micrometeorological variables collected at prior to three days interval were regressed against the per cent disease index collected on the corresponding days. The six days lead time $\left(\mathrm{LT}_{6}\right)$ means the data on agrometeorological and micrometeorological variables collected in advance to six days interval were regressed against the per cent disease index value collected on the corresponding days. The lead time concept was first introduced by Venkatesh et al., (2001a) and Venkatesh et al., (2001b) to predict the grape diseases. Same method was adopted by Mahesh (2018) and 
Amith (2018) for forewarning soybean pest and disease incidence. Venkatesh and Balikai (2008) worked on Weather and Pests: Research Highlights of AICRPAM Bijapur Centre. Publication Centre, UAS Dharwad. The same concept was used by Balikai and Venkatesh (2001, 2002 and 2019) to predict sorghum pest. It was also used by Mahesh Kumar et al., (2009) to predict mealy bugs in grape and the same concept was used here for forewarning maize disease.

\section{Results and Discussion}

The incidence of turcicum leaf blight diseases of maize observed in different growing environments $\left(\mathrm{GE}_{1}, \mathrm{GE}_{2}\right.$, and $\left.\mathrm{GE}_{3}\right)$, are presented in Fig. In the first growing environment turcicum leaf blight was noticed at 78 DAS the disease grade reached 38.2 (PDI). In the second growing environment disease was noticed at 63 DAS and the disease grade of turcicum leaf blight reached 65.4 (PDI). In the third growing environment, the diseases noticed at 48 DAS, the disease grade of turcicum leaf blight reached 78.9 (PDI).

From this it can be inferred that disease grade was positively correlated with the relative humidity this result showed that during the disease initiation the relative humidity was $>70$ per cent (for all growing environment) with slight rainfall, this can be taken as weather was congenial for disease initiation this can also taken as a thumb rule for disease initiation. The disease grade of TLB was negatively correlated with morning air temperature, afternoon air temperature and mean air temperature.

Statistical models were developed for realtime [lead time zero $\left(\mathrm{LT}_{0}\right)$ ], by regressing disease grades with agrometeorological and micrometeorological weather parameters. These are weather based disease estimation models, because they have no predictive value. The full model disease estimation model of 18 variables developed for tucicum leaf blight (TLB) presented in table 01, indicates that the disease grade with different weather parameters accounted for 86 per cent variability of TLB disease incidence with only one variable $\left(\mathrm{X}_{21}\right)$ showing statistical significance. From the results of stepwise regression analysis performed to optimize the dependent variables, only few variables viz., $\mathrm{X}_{26}, \mathrm{X}_{14}, \mathrm{X}_{30}, \mathrm{X}_{29}$ and $\mathrm{X}_{28}$ were considered, and the model could explain the variability in TLB incidence to the extent of 77 per cent.

Results of correlation and regression analysis performed between disease grades and agrometeorological and micrometeorological data at lead time of three days $\left(\mathrm{LT}_{3}\right)$ and six days $\left(\mathrm{LT}_{6}\right)$. The results also revealed that disease grade was positively correlated with the morning relative humidity at top of canopy, morning relative humidity at middle of canopy and morning relative humidity at bottom of canopy $\left(\mathrm{X}_{13}, \mathrm{X}_{16}\right.$ and $\mathrm{X}_{19}$ respectively) as well as with the afternoon relative humidity in the observatory $\left[\mathrm{X}_{26}\right]$ at $\mathrm{LT}_{3}$ and $\mathrm{LT}_{6}$ also. However, the disease grade of TLB was negatively correlated with $\mathrm{X}_{23}$ at both the lead times. It was also noticed that, the correlation coefficients of micrometeorological variables and agrometeorological variables are almost same in case of turcicum leaf blight $\mathrm{LT}_{3}$ and $\mathrm{LT}_{6}$, This indicates the importance of micrometeorological variables along with agrometeorological variables in disease incidences.

The three days, lead time $\left(\mathrm{LT}_{3}\right)$ in table 02 full model disease estimation model of 17 variables developed for turcicum leaf blight presented, indicates that the disease grade with different weather parameters accounted for 82 per cent variability of TLB disease incidence with only one variable $\left(\mathrm{X}_{26}\right)$ showing statistical significance. 
Table.1 Regression analysis for turcicum leaf blight disease incidence

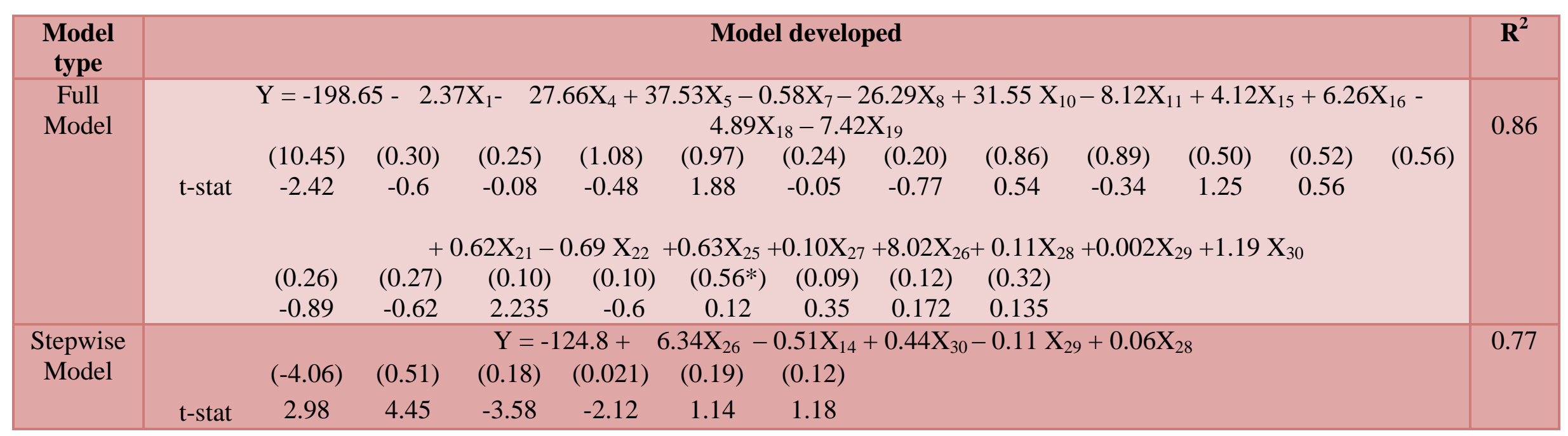

Table.2 Regression analysis for predicting turcicum leaf blight of maize disease incidence at three days lead-time (LT 3 )

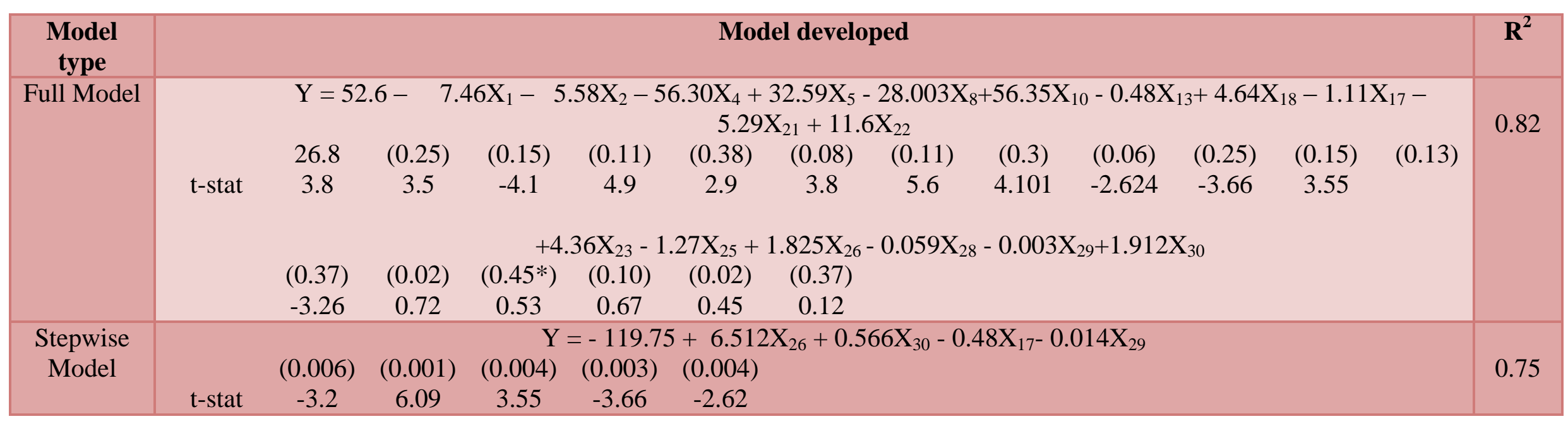


Table.3 Regression analysis for predicting turcicum leaf blight of maize disease incidence at six days lead-time (LT 6$)$

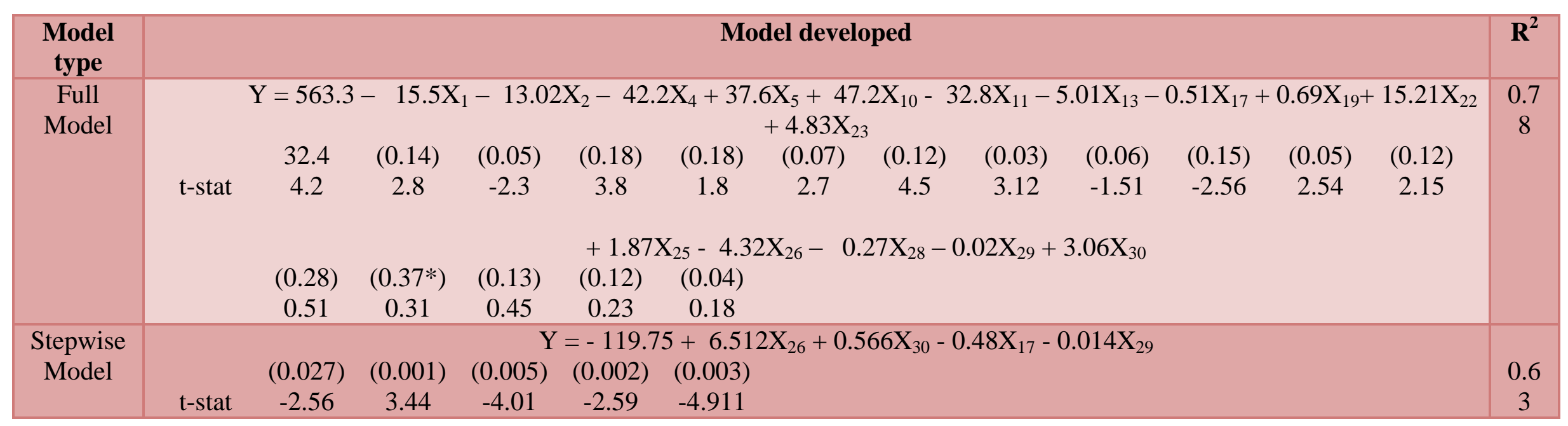

\begin{tabular}{|c|c|c|c|}
\hline Variables & \multicolumn{1}{|c|}{ Description } & Variables & Description \\
\hline $\mathrm{X}_{1}$ & Morning Canopy temperature & $\mathrm{X}_{17}$ & Afternoon Relative Humidity at middle level of canopy \\
\hline $\mathrm{X}_{2}$ & Afternoon Canopy temperature & $\mathrm{X}_{18}$ & Diurnal range of Relative Humidity middle level of canopy \\
\hline $\mathrm{X}_{3}$ & Diurnal range of Canopy temperature & $\mathrm{X}_{19}$ & Morning Relative Humidity at bottom of canopy \\
\hline $\mathrm{X}_{4}$ & Morning Air Temperature at top level of canopy & $\mathrm{X}_{20}$ & Afternoon Relative Humidity at bottom of canopy \\
\hline $\mathrm{X}_{5}$ & Afternoon Air Temperature at top level of canopy & $\mathrm{X}_{21}$ & Diurnal range of Relative Humidity at bottom of canopy \\
\hline $\mathrm{X}_{6}$ & Diurnal range of Air Temperature at top level of canopy & $\mathrm{X}_{22}$ & Morning air temperature at Observatory \\
\hline $\mathrm{X}_{7}$ & Morning Air Temperature at middle level of canopy & $\mathrm{X}_{23}$ & Afternoon air temperature in Observatory \\
\hline $\mathrm{X}_{8}$ & Afternoon Air Temperature at middle level of canopy & $\mathrm{X}_{24}$ & Diurnal range of air temperature in Observatory \\
\hline $\mathrm{X}_{9}$ & Diurnal range of Air Temperature at middle level of canopy & $\mathrm{X}_{25}$ & Morning Relative Humidity in Observatory \\
\hline $\mathrm{X}_{10}$ & Morning Air Temperature at bottom of canopy & $\mathrm{X}_{26}$ & Afternoon Relative Humidity in Observatory \\
\hline $\mathrm{X}_{11}$ & Afternoon Air Temperature at bottom of canopy & $\mathrm{X}_{27}$ & Diurnal range of Relative Humidity in Observatory \\
\hline $\mathrm{X}_{12}$ & Diurnal range of Air Temperature at bottom of canopy & $\mathrm{X}_{28}$ & Morning time absorptance of radiation by canopy \\
\hline $\mathrm{X}_{13}$ & Morning Relative Humidity at top level of canopy & $\mathrm{X}_{29}$ & Afternoon time absorptance of radiation by canopy \\
\hline $\mathrm{X}_{14}$ & Afternoon Relative Humidity at top level of canopy & $\mathrm{X}_{30}$ & Cumulative rainfall during cropping period \\
\hline $\mathrm{X}_{15}$ & Diurnal range of Relative Humidity at top level of canopy & $\mathrm{Y}$ & Disease grades (PDI) \\
\hline $\mathrm{X}_{16}$ & Morning Relative Humidity at middle level of canopy & & \\
\hline
\end{tabular}


From the results of stepwise regression analysis performed to optimize the dependent variables, only four variables viz., $\mathrm{X}_{26}, \mathrm{X}_{30}, \mathrm{X}_{17}$ and $\mathrm{X}_{29}$ were considered, and the model could explain the variability in TLB incidence to the extent of 75 per cent.

At six days, lead time $\left(\mathrm{LT}_{6}\right)$ in table 03 full model disease estimation, the full model with 16 variables developed for turcicum leaf blight disease (TLB) indicates that the disease grade with different weather parameters accounted for 78 per cent variability of TLB disease incidence with only one variable $\left(\mathrm{X}_{26}\right)$ showing statistical significance.

From the results of stepwise regression analysis performed to optimize the dependent variables, only four variables viz., $\mathrm{X}_{26}, \mathrm{X}_{30}, \mathrm{X}_{17}$ and $\mathrm{X}_{29}$ were considered, and the model could explain the variability in TLB incidence to the extent of 63 per cent.

The severity of diseases over a geographical area is not only dependent on weather factors, but also the survival mechanism of pathogenic propagules in soil, seed and water, and also degree of virulence and the extent of sporulation are influenced by weather parameters. The disease was noticed earlier in (63 DAS) $\mathrm{GE}_{2}$ and (48 DAS) $\mathrm{GE}_{3}$ compared to $\mathrm{GE}_{1}$ (80 DAS), hence the role of meteorological factors in disease is supported. In the lead time concept, the results indicated that weather variables viz., the morning relative humidity at top of canopy, morning relative humidity at middle of canopy and morning relative humidity at bottom of conopy ( $\mathrm{X}_{13}, \mathrm{X}_{16}$ and $\mathrm{X}_{19}$ respectively) as well as with the afternoon relative humidity in the observatory $\left[\mathrm{X}_{26}\right]$ at $\mathrm{LT}_{3}$ and they could explain the variability in disease incidence to an extent of 82 per cent when compared to $\mathrm{LT}_{6}$. From the lead times, the $\mathrm{LT}_{3}$ is the best for the forewarning of turcicum leaf blight (TLB) disease.

\section{References}

Amith, G., 2018, Studies on weather and diseases relationships in soybean. $M$. Sc. (Agri.) Thesis, Univ. Agric. Sci., Dharwad, Karnataka (India).

Anonymous, 2017, Area, production and productivity of maize in India and Karnataka. www.Indiastat.com.

Balikai R A and Venkatesh H, 2001, Influence of weather factors on the incidence of sorghum shoot fly, Atherigona soccata Rondani in rabi. Insect Environment, 7(3): 123.

Balikai R A and Venkatesh H, 2019, Weather based prediction models to forecast major pests of rabi sorghum in Karnataka, India. Journal of Experimental Zoology India, 22(1): 131-134.

Mahesh, H., 2018, Studied on relationship of weather on incidence of insects pests in soybean. M. Sc. (Agri.) Thesis, Univ. Agric. Sci., Dharwad, Karnataka (India).

Maheshkumar K, Balikai R A and Venkatesh H, 2009, Seasonal incidence of grape mealy bug, Maconellicoccus hirsutus (Green) and its relation with weather parameters. Pest Management in Horticultural Ecosystems, 15(1): (916).

Payak, M. M. and Sharma, R. C., 1982, Maize diseases and approaches to their management in India. Trop. Pest Mngt., 31: 302-310.

Venkatesh H and Balikai R A, 2002, Influence of weather variables on the incidence of sorghum shootfly in rabi season. Journal of Agrometeorology, 4 (1): 3944.

Venkatesh, H., Jahagiradar, S. and Jamadar, M. M., 2001a, On influence of weather variables on downy mildew disease of grape in Northern Karnataka. Natl Symp. Agromet., Gujarat Uni. Agric. 
Anand. (India), pp. 27-28.

Venkatesh, H., Jamadar, M. M. and Jahagirdar, S., 2001b, Meteorological influence on anthracnose of grapes in
Northern Karnataka. Natl Symp. Agromet., Gujarat Univ. Agric. Anand. (India), pp. 27-28.

\section{How to cite this article:}

Vishal Meti, K. G. Sumesh, H. Venkatesh and Harlapur, S. I. 2021. Effect of Agrometeorological Parameters on Turcicum Leaf Blight Disease of Maize in Northern Transition Zone of Karnataka. Int.J.Curr.Microbiol.App.Sci. 10(08): 149-155. doi: https://doi.org/10.20546/ijcmas.2021.1008.019 